\title{
BIOADSORPSI Fe(II) OLEH KULIT BUAH JERUK Citrus nobilis Lour. var microcarpa TERMODIFIKASI $\mathrm{Ca}(\mathrm{OH})_{2}$
}

\author{
Norvi Fatmawati*, Thamrin Usman, Titin Anita Zahara \\ Program Pascasarjana Kimia, Fakultas Matematika dan Ilmu Pengetahuan Alam, Universitas \\ Tanjungpura Jl. Prof. Dr. H. Hadari Nawawi, Pontianak, Indonesia \\ "Corresponding author: norvisari75@gmail.com
}

\begin{tabular}{l}
\hline ARTICLE INFO \\
Article history: \\
Received 18 \\
November 2018 \\
Accepted 30 December \\
2018 \\
Available online 30 \\
December 2018 \\
Keywords: \\
adsorpsi, besi, kulit \\
jeruk, karakterisasi, \\
kinetika isoterm
\end{tabular}

\section{Pendahuluan}

(c) 2018 IJoPAC. All rights reserved

Pontianak peel fruit waste contains pectin, cellulose, and hemicellulose which can be used as heavy metal adsorbents by modifying using $\mathrm{Ca}(\mathrm{OH})_{2}$. The purpose of this study was to determine the physicochemical characteristics of calcium-modified Pontianak Citrus adsorbents (JeP-Oca), determine the maximum capacity of $\mathrm{Fe}$ (II) adsorption by JeP-OCa, and JeP-OCa adsorption kinetics. The characteristics of the adsorbent were analyzed using the Fourier Transformation Infra Red (FTIR) showing the functional groups of $\mathrm{OH}$ and $-\mathrm{COOH}$, Electron Scanning (SEM) Microscopy showing the surface structure of the canal and many irregular niches. The adsorption isotherm method with the BET model showed a large difference in porous surface area, namely $104.872 \mathrm{~m}^{2} / \mathrm{g}$ for JeP, $242.649 \mathrm{~m}^{2} / \mathrm{g}$ for JeP-ONa and $3759.745 \mathrm{~m}^{2} / \mathrm{g}$ for JeP-OCa. Optimization of the influence of $\mathrm{pH}$, adsorbent mass, adsorbate concentration, and time using the column method. Adsorption isotherm followed the Freundlich isotherm model with maximum adsorption capacity value of $22.7272 \mathrm{mg} / \mathrm{g}$. Fulfill the pseudo-order 2 reaction kinetics with a rate constant value of $4.097 \mathrm{~L} / \mathrm{mg}$. Min. The adsorption application using groundwater resulted in absorption efficiency of $82.99 \%$.

Ketersediaan air bersih merupakan kebutuhan pokok bagi masyarakat untuk berbagai aktifitas, baik aktifitas domestik (rumah tangga) maupun aktifitas nondomestik. Untuk memenuhi kebutuhan terhadap air yang berkualitas, air harus memenuhi syarat secara fisik, kimia, biologi dan radioaktifitas. Kualitas air secara kimia berhubungan dengan kandungan bahan-bahan kimia yang tidak melampaui batas, antara lain $\mathrm{pH}$, kesadahan, kalsium (Ca), besi $(\mathrm{Fe})$, mangan $(\mathrm{Mn})$, tembaga $(\mathrm{Cu})$, seng $(\mathrm{Zn})$, klorida $(\mathrm{Cl})$, nitrit, flourida $(\mathrm{F})$, serta logam berat lain.

Di Kalimantan Barat keberlimpahan airnya tidak diiringi dengan kualitas air bersih sesuai baku mutu. Untuk parameter besi (Fe) berdasarkan hasil analisa kualitas kimiawi logam air 
gambut, untuk kandungan besi total (Fe) sebesar $0,414 \mathrm{mg} / \mathrm{mL}^{[1]}$. Angka ini diatas baku mutu air bersih sebesar 0,33 mg/mL ${ }^{[2]}$. Meskipun besi dibutuhkan dalam proses untuk menghasilkan oksidasi enzim cytochrome dan pigmen pernapasan (hemoglobin), namun logam ini akan menjadi racun apabila keadaannya terdapat dalam konsentrasi diatas normal. Tingginya konsentrasi $\mathrm{Fe}$ dapat menyebabkan gangguan kesehatan seperti gangguan pada usus dan menyebabkan kanker ${ }^{[3]}$. Kelebihan zat besi ( $\mathrm{Fe}$ ) pada tubuh manusia juga bisa menyebabkan keracunan, diare dan gangguan pada ginjal, serta bisa meningkatkan risiko penyakit jantung, yakni mendorong pembentukan plak (kerak) di dinding pembuluh arteri, sehingga terjadi aterosklerosis, yaitu dinding pembuluh arteri jadi tebal dan mengeras ${ }^{[4]}$. Artinya logam berat tersebut memiliki dampak negatif terhadap manusia jika dikonsumsi dalam jumlah yang besar dalam waktu yang lama.

Beberapa metode untuk menghilangkan kontaminasi logam berat didalam air sudah dilakukan, yang sudah pernah dilakukan antara lain menggunakan membran keramik ${ }^{[4]}$, menggunakan metode koagulasi-flokulasi $i^{[5]}$, menggunakan tumbuhan air sebagai agen fitoremediator $^{[6]}$. Bioadsorpsi merupakan salah satu teknik yang paling populer. Hal ini disebabkan bioadsorpsi memiliki kelebihan, seperti murah, ramah lingkungan, dan dapat digunakan kembali ${ }^{[7]}$. Sekarang ini, biopolimer termodifikasi merupakan biomaterial adsorben yang ekonomis dan efektif. Salah satu biomaterial prospektif tersebut adalah limbah kulit buah jeruk Pontianak (JeP).

Produksi jeruk Pontianak dalam rentang 2006-2009 rata-rata berkisar 149.377,25 ton pertahun ${ }^{[8]}$. Tidak kurang dari 15.000 ribu ton merupakan limbah kulit buahnya.. Limbah kulit buah jeruk Pontianak menimbulkan efek lain, yakni jika tidak didayagunakan dapat menimbulkan pencemaran lingkungan. Penelitian terdahulu telah menyatakan bahwa limbah kulit buah jeruk mengandung senyawa polimer karbohidrat berupa pektin dan selulosa yang merupakan polimer karbohidrat yang paling banyak terdapat di dalam kulit buah jeruk ${ }^{[9],[10]}$. Hal ini menunjukkan bahwa Jeruk Pontianak (JeP) juga diduga memiliki kandungan yang sama berupa pektin dan selulosa sebagai komponen utama.Sejauh ini kulit jeruk sudah dimanfaatkan kandungan pektin, limonena dan minyak atsirinya Hal ini membuka peluang adanya diversifikasi JeP menjadi suatu adsorben logam berat dengan memodifikasinya.

Beberapa penelitian terdahulu melaporkan bahwa modifikasi limbah kulit jeruk Citrus kinokuni hort. ex Tanaka dengan $\mathrm{Ca}(\mathrm{OH}) 2$ dapat diaplikasikan pada proses adsorpsi $\mathrm{Mo}(\mathrm{VI})^{[11]}$. Saponifikasi kulit jeruk dengan $\mathrm{Ca}(\mathrm{OH})_{2}$ dan diaktivasi zirconium mampu mengurangi konsentrasi arsenic dan fosfor didalam air ${ }^{[12]}$, sedangkan saponifikasi kulit jeruk Citrus nobilis var. Microcarpa dengan $\mathrm{NaOH}$ dan $\mathrm{Ca}(\mathrm{OH})_{2}$ memiliki kemampuan dalam mengadsorpsi $\mathrm{Pb}$ $\left(\right.$ II) ${ }^{[13]}$.

Secara kimiawi komponen utama kulit jeruk mengandung selulosa, hemiselulosa, dan lignin dalam bentuk karboksil dan hidroksil yang menghasilkan afinitas tinggi terhadap ion logam ${ }^{[11]}$. Modifikasi kulit jeruk menggunakan $\mathrm{Ca}(\mathrm{OH})_{2}$ akan membuka atau mengubah gugus hidroksil, karboksil dan metil dalam bentuk resin penukar ion. Berdasarkan beberapa hasil penelitian diatas, JeP diduga juga dapat dimodifikasi dengan $\mathrm{Ca}(\mathrm{OH}) 2$ menjadi JeP-OCa yang diharapkan dapat diaplikasikan sebagai adsorben logam berat Fe (II) dalam larutan berair.

Monomer penyusun pektin merupakan asam galakturonat dan metil- $\alpha$-galakturonat. Baik pektin maupun selulosa, keduanya memiliki gugus hidroksil bebas yang dapat dimodifikasi pada posisi atom $C 3$ dan $C 6^{[11]}$. 

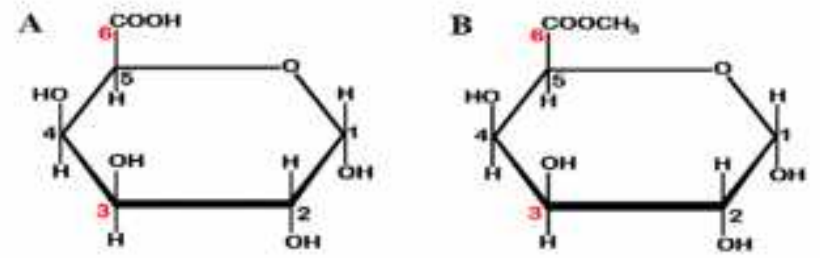

Gambar 1. Monomer A. asam galakturonat ; B. metil $-\alpha$ - galakturonat (Sumber : ${ }^{[14]}$ )

Analisis FTIR digunakan untuk mengkonfirmasi gugus fungsional. Metode Scanning Electron Microscopy (SEM) untuk mengetahui struktur mikro suatu material, Karakterisasi luas permukaan adsorben dikonfirmasi melalui metode isoterm adsorpsi gas $\mathrm{N}_{2}$ dengan model BET (Bruneur-Emmet_Teller).

\section{Bahan dan Metode}

\subsection{Bahan}

Alat yang digunakan pada penelitian ini diantaranya adalah Spektrofotometer Serapan Atom (SSA), tanur, oven, desikator, ayakan 80 mesh, blender, $\mathrm{pH}$ meter, neraca analitik, statif, klem, dan kolom kromatografi.

Bahan yang digunakan dalam penelitian ini diantaranya berupa limbah kulit buah jeruk Pontianak (JeP) yang diperoleh dari sisa penjualan jus buah. Reagen $\mathrm{Fe}\left(\mathrm{NO}_{3}\right)_{2} \cdot \mathrm{H}_{2} \mathrm{O}, \mathrm{H}_{2} \mathrm{SO}_{4}$ pekat, aquades (Cleo) dan $\mathrm{Ca}(\mathrm{OH})_{2}$. Bahan kimia yang digunakan berasal dari Merck (Darmstadt, Jerman). Semua reagen kimia umum yang digunakan pada penelitian ini memenuhi standar laboratorium.

Adapun instrument analitik yang digunakan pada penelitian ini diantaranya, spektrofotometer FTIR (SHIMADZU), BET dengan Quantachrome instruments versi 11,0 dan SEM (ZEISS).

Penelitian ini dilakukan di Laboratorium Kimia Fakultas Matematika dan Ilmu Pengetahuan Alam Universitas Tanjungpura Pontianak. Waktu pelaksanaan penelitian berlangsung dari bulan Desember 2015 - April 2016.

\subsection{Metode}

Metode penelitian ini dibagi ke dalam tiga tahap. Tahap pertama adalah sintesis dan karakterisasi fisikokimia JeP-OCa sebelum proses adsorpsi. Tahap kedua adalah isoterm adsorpsi dan kinetika adsorpsi JeP-OCa sesudah proses adsorpsi, tahap ketiga adalah aplikasi JeP-OCa sebagai bioadsorben Fe (II) dalam larutan berair berdasarkan parameter yang ada.

Tahap 1. Preparasi adsorben JeP-OCa

1. Persiapan sampel kulit jeruk Pontianak.

Kulit jeruk Pontianak sebelum dimodifikasi dibersihkan dengan cara dicuci kemudian dipotong kecil-kecil, dengan tujuan untuk mempercepat proses pengeringan pada kulit jeruk. Potongan kulit jeruk Pontianak kemudian dijemur dibawah sinar matahari selama 23 hari hingga diperoleh JeP yang benar- benar telah kering ${ }^{[15]}$

2. Modifikasi kulit jeruk Pontianak oleh $\mathrm{Ca}(\mathrm{OH})_{2}$

Kulit jeruk Pontianak yang dihasilkan dari proses sebelumnya kemudian dihaluskan dan diayak menggunakan ayakan ukuran 80 mesh. Setelah didapatkan ukuran yang seragam, sebanyak 100 gram JeP direndam didalam larutan $\mathrm{NaOH}$ 0,1 M selama 24 jam $^{[16]}$. Perendaman dengan $\mathrm{NaOH}$ bertujuan untuk menghilangkan lignin pada JeP. Selanjutnya dilakukan dekantasi hingga air perendaman netral. JeP dikeringkan di oven pada suhu $105^{\circ}$ 
$C$ hingga kadar air kurang dari $10 \%$. Setelah itu dilakukan proses modifikasi JeP dengan $\mathrm{Ca}(\mathrm{OH})_{2}$ dengan perbandingan $1: 1$ sambil diaduk dengan pengaduk magnetik selama 5 jam dengan laju $200 \mathrm{rpm}$. Setelah itu suspensi didekantasi hingga $\mathrm{pH}$ netral, disaring, dikeringkan, dan padatan yng didapat disimpan dalam wadah plastik kedap udara yang dinyatakan sebagai JeP-OCa untuk analisis lebih lanjut.

3. Pembuatan larutan stok Fe (II)

Sebanyak 3,5 gram $\mathrm{Fe}\left(\mathrm{NO}_{3}\right)_{2} \cdot \mathrm{H}_{2} \mathrm{O}$ dilarutkan ke dalam $100 \mathrm{~mL}$ akuades. Selanjutnya, larutan tersebut ditambahkan beberapa tetes $0,1 \mathrm{M} \mathrm{H}_{2} \mathrm{SO}_{4}$ pekat. Selanjutnya, akuades ditambahkan hingga volume larutan tepat $1 \mathrm{~L}$. Selanjutnya, larutan stok tersebut dibuat berbagai variasi konsentrasi $(0,50,100,250,500$, dan 1000 ppm) dengan volume masingmasing $50 \mathrm{~mL}$ melalui metode pengenceran.

4. Karakterisasi fisikokimia JeP-OCa

a. Analisis spektrofotometer Transformasi Fourier Transform Infra Red (FTIR). Penentuan gugus fungsi dari sampel diuji dengan spektrofotometer FTIR dalam pelet $\mathrm{KBr}$ yang mengandung 1\% sampel pada panjang gelombang 4000 - $400 \mathrm{~nm}$.

b. Karakterisasi morfologi permukaan dengan Scanning Electron Microscopy (SEM). Pemayaran objek sampel diamati dengan perbesaran 100x - 1000x.

c. Karakterisasi luas permukaan menggunakan metode adsorpsi-desorpsi gas dengan persamaan BET (Bruneur- Emmet- Teller)

Tahap 2. Karakterisasi adsorpsi Fe(II) oleh JeP-OCa

1. Pengaruh $\mathrm{pH}$, massa adsorben, konsentrasi adsorbat terhadap adsorpsi $\mathrm{Fe}(\mathrm{II})$ oleh JeP-OCa

a. Pengaruh $\mathrm{pH}$

Sebanyak $25 \mathrm{~mL}$ larutan Fe (II) 50 ppm pada wadah terpisah diatur pada variasi $\mathrm{pH}$ 2,0; 3,$0 ; 4,0 ; 5,0 ; 6,0 ; 7,0 ;$ dan 8,0. Larutan tersebut ditambahkan 0,75 gram JeP-OCa yang didapat pada poin (b).Suspensi tersebut dialirkan menggunakan kolom kromatografi. Jumlah Fe(II) yang teradsorpsi tersebut dihitung adsorbansinya menggunakan AAS.

b. Pengaruh massa adsorben

Sebanyak 0,25; 0.5; 0,75 ; 1,00; dan 1,25 gram JeP-OCa dimasukkan ke dalam kolom kromatografi pertukaran kation dan ditambahkan $25 \mathrm{~mL}$ larutan sampel Fe (II) $50 \mathrm{ppm}$ yang diatur pada $\mathrm{pH} 4,0$. Jumlah $\mathrm{Fe}(\mathrm{II})$ yang teradsorpsi tersebut dihitung adsorbansinya menggunakan AAS ${ }^{[17]}$

c. Pengaruh konsentrasi adsorbat

Sebanyak 25 mL larutan Fe (II) (25, 50, 100, 200, dan 400 ppm) pada wadah terpisah diatur pada $\mathrm{pH}$ 4.00. Larutan tersebut ditambahkan sebanyak 1.0 gram JeP-OCa. Sebanyak $0.1 \mathrm{M}$ larutan $\mathrm{H}_{2} \mathrm{SO}_{4}$ digunakan untuk mengatur nilai $\mathrm{pH}$ larutan tersebut. Setelah itu, konsentrasi Fe (II) yang telah diadsorpsi pada kolom kromatografi pertukaran kation ditentukan adsorbansinya menggunakan AAS.

\section{Isoterm adsorpsi.}

Sebanyak $25 \mathrm{~mL}$ larutan Fe (II) dengan variasi konsentrasi 50 ppm diatur pada $\mathrm{pH}=4.00$ kemudian dikolom selama 5 menit. Larutan tersebut selanjutnya ditentukan adsorbansinya menggunakan AAS. Data yang diperoleh selanjutnya dihitung dan diolah secara grafik berdasarkan Persamaan 1, 2, dan 3.

$$
\begin{aligned}
& \mathrm{Ce} / \mathrm{Qe}=\mathrm{Ce} / \mathrm{Qm}+1 /(\mathrm{QmKL}) \\
& \log \mathrm{Qe}=(1 / \mathrm{n}) \ln \mathrm{Ce}+\log \mathrm{KF} \\
& \mathrm{Qe}=(\mathrm{Ci}-\mathrm{Cf}) . \mathrm{V} / \mathrm{W}
\end{aligned}
$$


3. Kinetika bioadsorpsi Fe (II) oleh JeP-OCa.

Sebanyak $25 \mathrm{~mL}$ larutan Fe (II) 50 ppm pada wadah terpisah masing-masing diatur pada pH 4 dengan penambahan 0,75 gram JeP-Oca. Larutan tersebut dialirkan dengan waktu tunggu 2,5 mL/menit, 5,0 mL/menit, 7,5 mL/menit, dan $10 \mathrm{~mL} /$ menit. Jumlah Fe(II) yang teradsorpsi tersebut dihitung adsorbansinya menggunakan AAS.

Adapun persamaan yang digunakan adalah Persamaan 4 (orde 0), persamaan 5 (orde 1), persamaan 6 (orde 2). Persamaan 7 (Pseudo orde 1) dan persamaan 8 (pseudo orde 2) ${ }^{[18]}$.

$$
\begin{aligned}
& C e=-k 0 t+C 0 \\
& \ln C e=-k 1 t+\ln C 0 \\
& 1 / C e-1 / C o=k 2 t \\
& \log (q e-q t)=\log q e-\frac{k}{2,303} t \\
& \frac{t}{q t}=\frac{1}{k_{\cdot c e^{2}}}+\frac{1}{q e} t
\end{aligned}
$$

Tahap 3. Aplikasi Adsorben pada Air Tanah.

Air tanah yang digunakan diperoleh dari Jalan Darma Putra Pontianak Utara pada koordinat titik S $0^{\circ}$ 0'7.326”, E 109 2035.6748”. Air tanah yang telah dikondisikan pH optimumnya dipipet sebanyak $100 \mathrm{~mL}$ dan dimasukkan kedalam Erlenmeyer kemudian ditambahkan dengan massa adsorben optimum kemudian dikolom dengan waktu kolom optimum yang dilakukan secara triplo. Jumlah Fe(II) yang teradsorpi diukur adsorbansinya dengan AAS.

\section{Hasil dan Pembahasan}

\subsection{Karakteristik fisikokimia adsorben}

Preparasi adsorben kulit jeruk menggunakan $\mathrm{NaOH}$ selain untuk menghilangkan hemiselulosa, pigmen dan senyawa dengan massa molekul rendah, juga untuk membuat gugus $\mathrm{COOCH}_{3}$ pada permukaan kulit jeruk terhidrolisis menjadi gugus $\mathrm{COO}$ - sehingga meningkatkan jumlah gugus karboksilat ${ }^{[19]}$. Perlakuan ini membuat struktur permukaan yang lebih baik dan lebih luas pada adsorben.

Mekanisme reaksi penambahan $\mathrm{NaOH}$ sebagai berikut :

$$
\mathrm{R}-\mathrm{COO}-\mathrm{CH}_{3}+\mathrm{NaOH} \rightarrow \mathrm{R}-\mathrm{COO}-+\mathrm{CH}_{3} \mathrm{OH}+\mathrm{Na}^{+}
$$

Gugus karboksil sampai pada batas tertentu bertanggung jawab untuk mengikat ion logam. Meningkatkan gugus tersebut dalam biomassa dapat meningkatkan kapasitas pengikatan logam. Selulosa, pektin, hemiselulosa dan lignin yang merupakan komponen utama JeP, mengandung metil ester yang tidak mengikat ion logam secara signifikan. Namun, metil ester ini bisa dimodifikasi menjadi ligan karboksilat dengan memberi perlakuan JeP dengan basa seperti natrium hidroksida ${ }^{[16]}$.

a. JeP

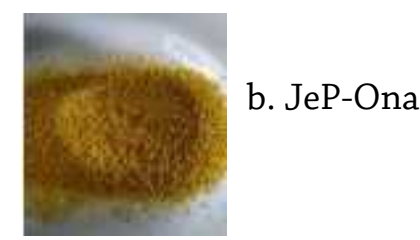

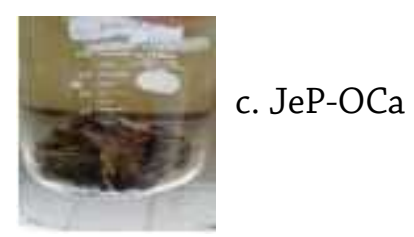

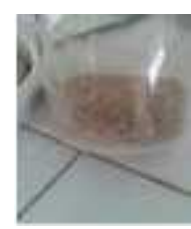

Gambar 3.1 modifikasi JeP (a) menjadi JeP-ONa (b) dan JeP-OCa (c) 
Gugus-gugus ini diperkaya lagi dengan modifikasi menggunakan $\mathrm{Ca}(\mathrm{OH})_{2}$ untuk meningkatkan kemampuan pertukaran ion. Adapun mekanisme pertukaran ion yang terjadi setelah dimodifikasi dengan $\mathrm{Ca}(\mathrm{OH})_{2}$ ditunjukkan melalui gambar 3.2 :

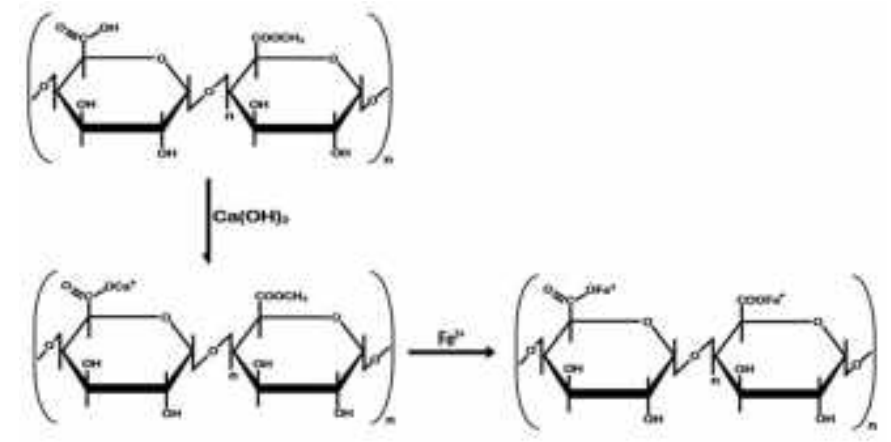

Gambar 3.2. Mekanisme pertukaran ion Fe(II) oleh JeP-OCa

Mekanisme pertukaran ion diatas adalah menukar ion yang terikat pada JeP-OCa dengan adsorbat yang dilewatkan, yaitu Fe(II). Dari reaksi tersebut jumlah ion $\mathrm{Ca}$ (II) yang ada pada adsorben diganti dengan ion Fe(II) dari larutan dengan jumlah yang setara. Menurut Wood dan Wang (1983) dalam Putra dan Fitri (2016) suatu kation dengan daya mempolarisasi tinggi lebih disenangi oleh ligan sebagai pusat muatan positif yang berkerapatan tinggi, sehingga menghasilkan interaksi yang lebih kuat. Daya mempolarisasi dipengaruhi oleh ukuran jari jari ion, semakin kecil jari-jari ion semakin tinggi daya mempolarisasinya. Jari jari ion $\mathrm{Ca}$ (II) sebesar $0,99 \mathrm{~A}^{\circ}$ sedangkan jari jari ion Fe(II) sebesar $0,75 \mathrm{~A}^{\circ}$.

由) SHIMADZU

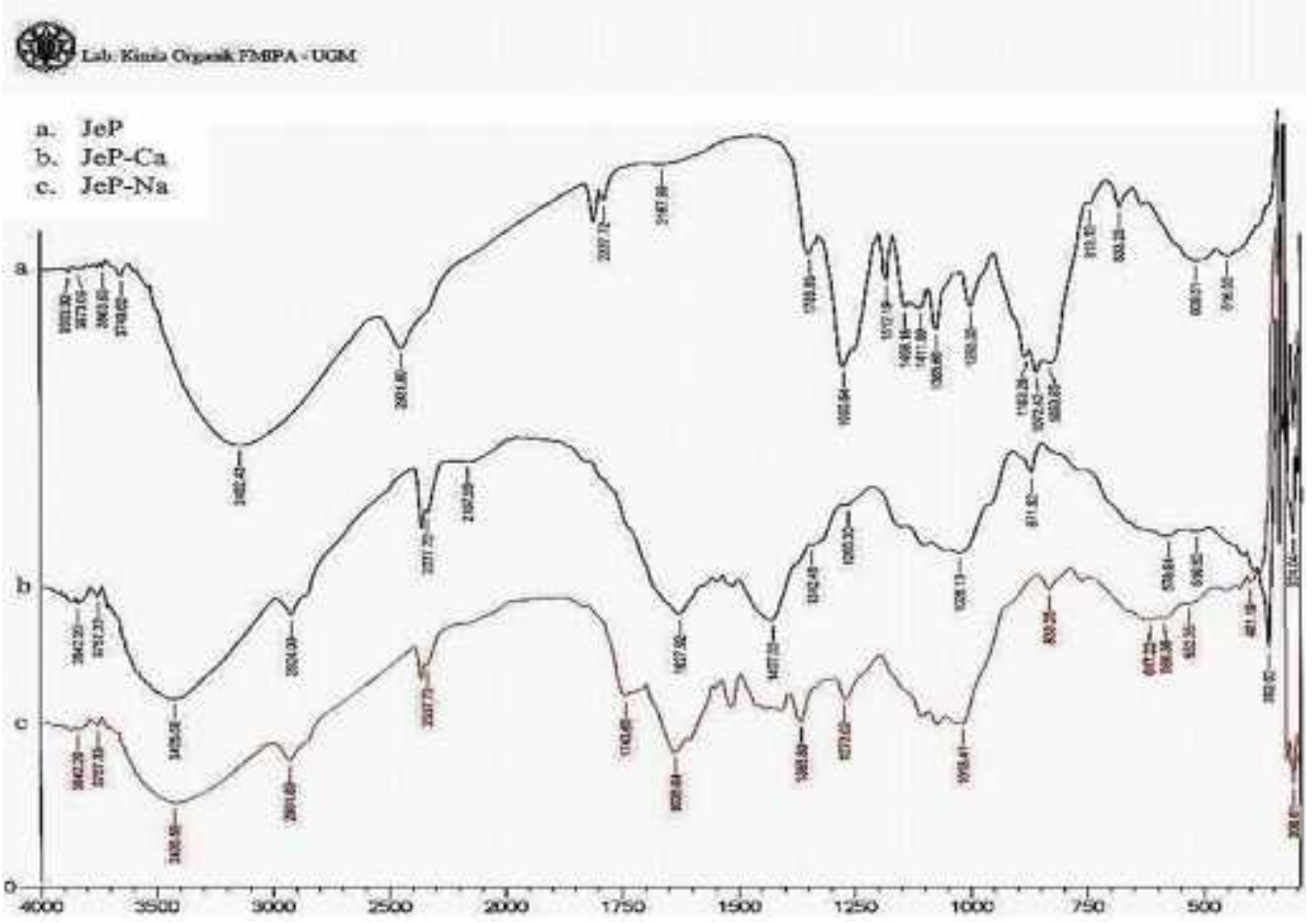

Gambar 3.3 Spektrum FTIR dari (A) JeP, (B) JeP- OCa, (C) JeP-ONa

Karakterisasi terhadap adsorben kulit jeruk (JeP) dan kulit jeruk termodifikasi (JeP-OCa) dilakukan berdasarkan spektrofotometri FTIR untuk mengkonfirmasi gugus fungsional (Gambar 3.3). SEM dan BET untuk mengkonfirmasi morfologi permukaan adsorben dan luas 
permukaan (Gambar 3.4 dan Gambar 3.5). Analisis FTIR yang digunakan untuk mengidentifikasi beberapa gugus fungsional pada JeP, JeP-OCa, JeP-ONa menunjukkan beberapa pola serapan sebagai berikut : Spektrum JeP-OCa menunjukkan puncak penyerapan yang lebar pada $3425,58 \mathrm{~cm}^{-1}$ yang sesuai dengan vibrasi peregangan $\mathrm{O}-\mathrm{H}$ dari alkohol dan asam karboksilat pada pektin, selulosa dan lignin. Ini menunjukkan adanya hidroksil bebas pada permukaan adsorben. Pada puncak 2924,09 $\mathrm{cm}^{-1}$ dapat dikaitkan dengan vibrasi peregangan C$\mathrm{H}$ dalam kelompok metil, metilena, dan metoksi. Pada puncak 1627,92 $\mathrm{cm}^{-1}$ menunjukkan adanya vibrasi peregangan $\mathrm{C}=\mathrm{O}$ pada gugus $\mathrm{COO}$ - dan pada puncak $1026,13 \mathrm{~cm}^{-1}$ menunjukkan vibrasi peregangan $\mathrm{C}-\mathrm{OH}$ dari gugus alkohol dan asam karboksilat. Adapun puncak $1735,93 \mathrm{~cm}^{-1}$ yang muncul pada JeP namun tidak muncul pada pita serapan JeP-OCa menunjukkan beberapa kelompok fungsional yaitu COO- yang berhasil dimodifikasi ${ }^{[19]}$. Adanya kesamaan puncak gelombang menunjukkan bahwa produk JeP-OCa memiliki pola spektrum yang tidak jauh berbeda dengan spektrum JeP sebelum modifikasi, hanya sedikit perubahan intensitas dan transmitan.

Tabel 2. Perbandingan karakteristik gugus fungsional kulit jeruk dari ${ }^{[16]}$ dengan hasil pengukuran kulit jeruk Pontianak

\begin{tabular}{|c|c|c|c|}
\hline \multicolumn{3}{|c|}{ Pita serapan IR $\left(\mathrm{cm}^{-1}\right)$} & \multirow[b]{2}{*}{ Keterangan } \\
\hline Literatur & $\begin{array}{c}\text { Hasil } \\
\text { penelitian } \\
\text { untuk JeP }\end{array}$ & $\begin{array}{l}\text { Hasil penelitian } \\
\text { untuk JeP-OCa }\end{array}$ & \\
\hline 3401,00 & 3425,58 & 3425,58 & $\begin{array}{l}\text { Vibrasi ulur gugus }-\mathrm{OH} \text { pada selulosa } \\
\text { dan pektin }\end{array}$ \\
\hline 2924,00 & 2931,80 & 2924,09 & $\begin{array}{l}\text { Vibrasi ulur } \mathrm{C} \text {-H simetrik dan } \\
\text { asimetrik kelompok metil, , etilena dan }\end{array}$ \\
\hline 1637,27 & 1635,64 & 1627,92 & $\begin{array}{l}\text { metoksi } \\
\text { Vibrasi ulur } \mathrm{C}=\mathrm{O} \text { pada gugus } \mathrm{COO}-\end{array}$ \\
\hline 1082,00 & 1033,35 & 1026,13 & ionik \\
\hline 1744,00 & 1735,93 & - & $\begin{array}{l}\text { Vibrasi ulur C-OH pada gugus alkohol } \\
\text { dan asam karboksilat } \\
\text { Vibrasi ulur COO- pada asam } \\
\text { karboksilat dan ester }\end{array}$ \\
\hline
\end{tabular}

Selanjutnya digunakan Metode Scanning Electron Microscopy (SEM) untuk mengetahui struktur mikro suatu material, yaitu struktur morfologi. Melalui metode ini permukaan tidak teratur dan berpori dapat diamati ${ }^{[21]}$.
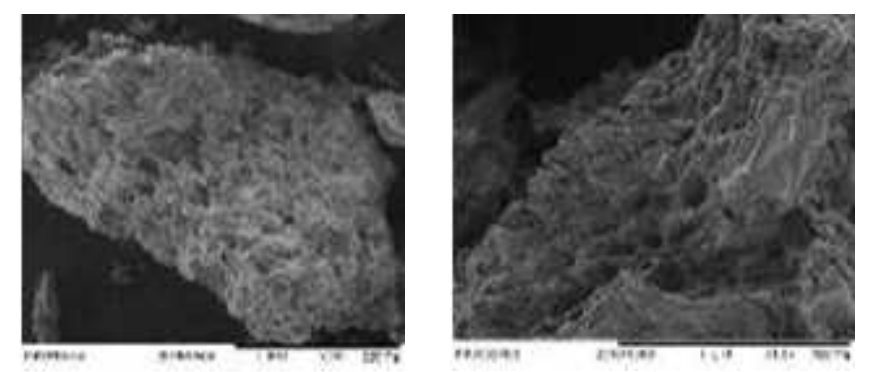

Gambar 3.4a Morfologi permukaan adsorben JeP pada perbesaran berturut-turut 250X, 1000X 

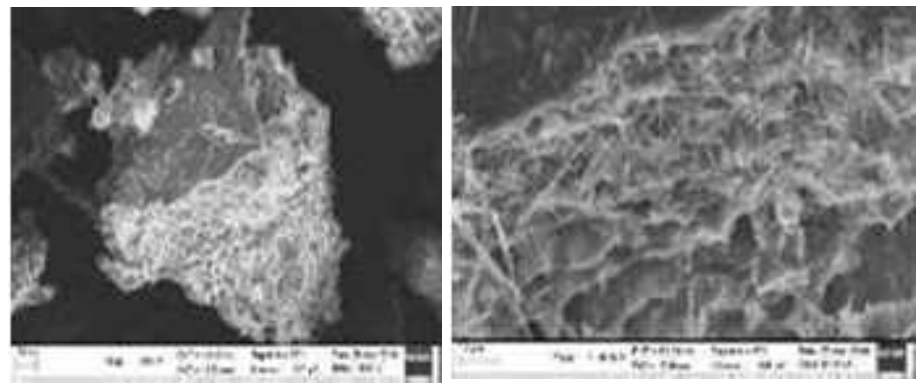

Gambar 3.4b Morfologi permukaan adsorben JeP-ONa sebelum modifikasi pada perbesaran berturut-turut 250X, 1000X
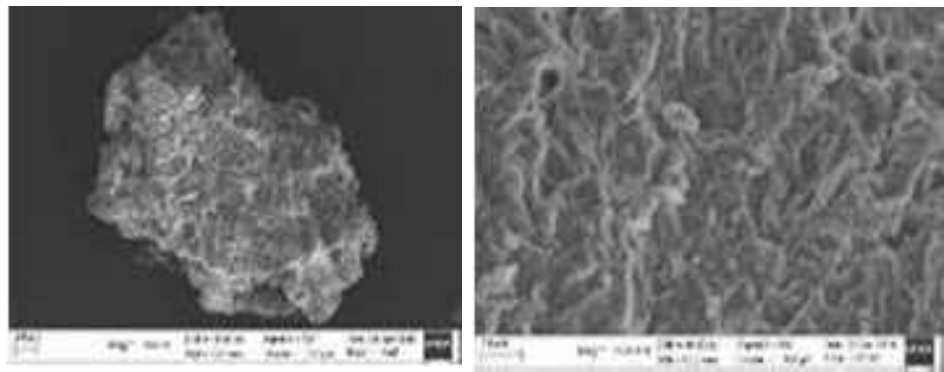

Gambar 3.4c Morfologi permukaan adsorben JeP-OCa sesudah modifikasi pada perbesaran berturutturut 250X, 1000X

Pada Gambar 3.4a, Gambar 3.4b, dan Gambar 3.4c menunjukkan morfologi permukaan yang berbeda sebelum dan sesudah dimodifikasi dengan $\mathrm{Ca}(\mathrm{OH})_{2}$. Gambar 3.4a memperlihatkan permukaan yang berpori dangkal, Gambar 3.4b memperlihatkan permukaan yang berpori dan berkanal, sedangkan pada gambar 4.4c kanal-kanal semakin tebal, struktur permukaan terlihat banyak relung-relung yang tidak teratur. Permukaan seperti ini memberi peluang pada adsorbat terperangkap lebih banyak ${ }^{[19]}$.

Berdasarkan hasil BET luas permukaan adsorben mengalami peningkatan signifikan, yaitu $104,872 \mathrm{~m}^{2} / \mathrm{g}$ untuk JeP, 242,649 m²/g untuk JeP-ONa dan 3759,745 m²/g untuk JeP-OCa (Lampiran 9). Hasil tersebut mengindikasikan bahwa proses modifikasi adsorben menggunakan $\mathrm{Ca}(\mathrm{OH})_{2}$ berhasil membuka struktur pori adsorben.

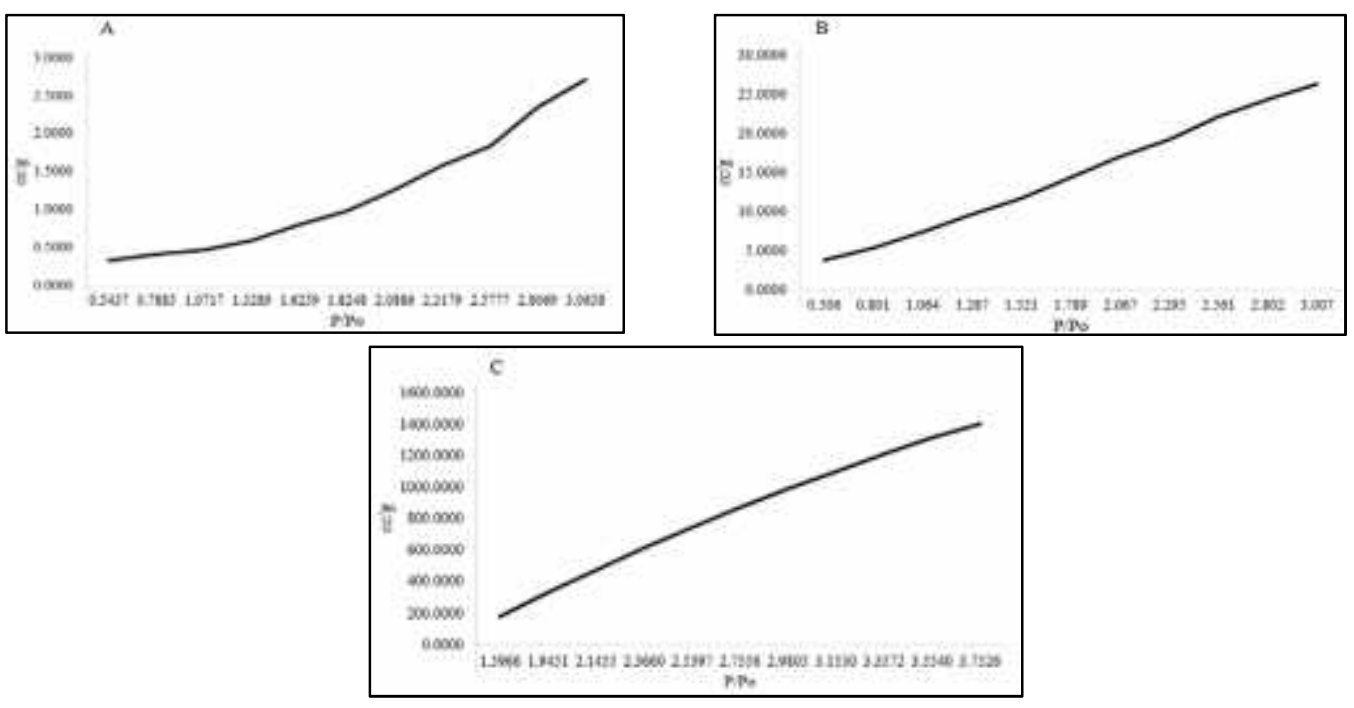

Gambar 3.5. Grafik Isoterm Adsorpsi $\mathrm{N}_{2}$ pada (A) JeP (B) JeP-ONa dan (C) JeP-OCa 


\subsection{Karakteristik Adsorpsi Fe(II) pada Adsorben}

Pengaruh $\mathrm{pH}$, massa adsorben, waktu, dan konsentrasi adsorbat merupakan parameter penting dalam penelitian ini, selain sebagai informasi untuk mengetahui kondisi optimum adsorpsi ion $\mathrm{Fe}(\mathrm{II})$ juga memberi informasi kinetika adsorpsi Fe(II) dalam larutan oleh JeP-OCa.

\subsubsection{Pengaruh $\mathrm{pH}$ terhadap jumlah ion Fe(II) teradsorpsi}

Nilai pH merupakan satu diantara parameter terpenting dalam proses adsorpsi yang dapat mempengaruhi kesetimbangan kimia pada adsorbat maupun pada adsorben.

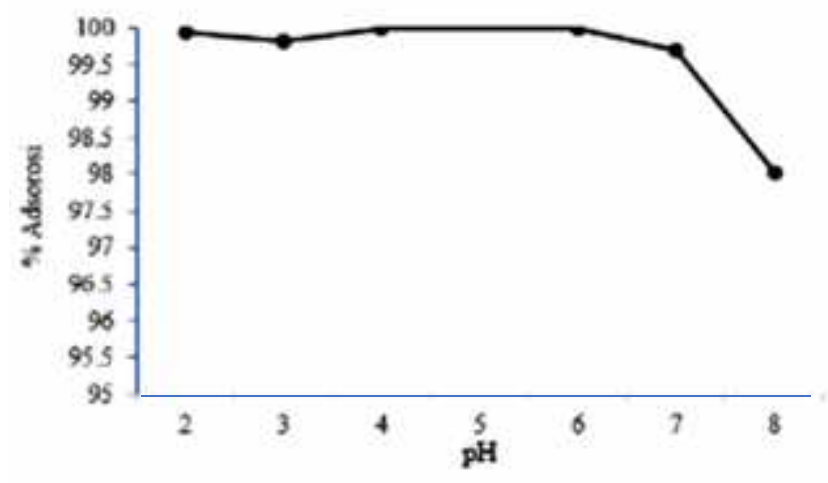

Gambar 3.6. Pengaruh pH larutan terhadap jumlah ion Fe(II) teradsorpsi

Berdasarkan Gambar 3.6 dapat dilihat kapasitas adsorpsi pada pH 2 tinggi, sedikit menurun pada pH 3 namun tidak signifikan, dan stabil pada pH 4, 5, dan 6. Menurut Guo (2010) pada pH rendah terjadi tolakan elektrostatik antar kation dengan permukaan adsorben yang bermuatan positif (terprotonisasi) dan efek persaingan dengan ion hidrogen menurun sehingga adsorpsi logam meningkat. Penurunan pada $\mathrm{pH} 7$ dan $\mathrm{pH} 8$ dikarenakan terjadi tolakan elektrostatik antar kation dengan gugus fungsi yang bermuatan negatif (terdeprotonisasi) dan terbentuk $\mathrm{FeOH}^{+}, \mathrm{Fe}(\mathrm{OH})_{2}$, atau kompleks $\left[\mathrm{Fe}(\mathrm{OH})_{4}\right]^{2-}$ yang mengurangi interaksi adsorbat dengan permukaan adsorben. Penelitian yang dilakukan oleh Feng (2010) menunjukkan adsorpsi maksimum $\mathrm{Cu}^{2+}$ menggunakan kulit jeruk terjadi antara $\mathrm{pH} 4,5-6$.

\subsubsection{Pengaruh massa adsorben terhadap jumlah ion Fe(II) teradsorpsi.}

Bertambahnya massa adsorben menyebabkan bertambahnya sisi aktif adsorpsi dan peningkatan efisiensi penyerapan seperti ditunjukkan pada gambar 3.7

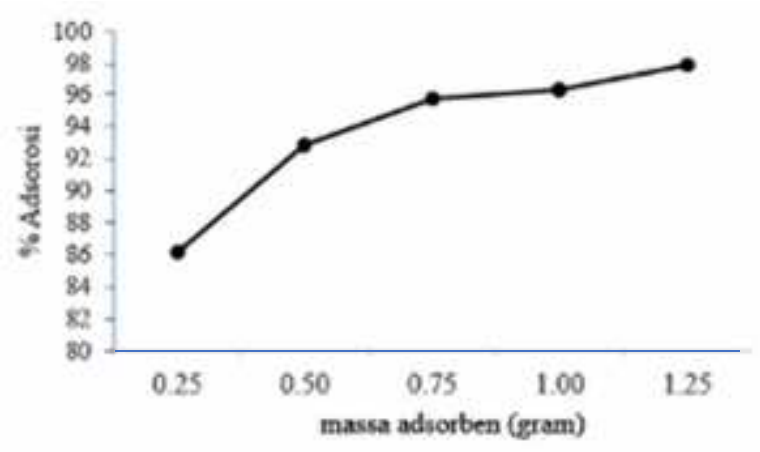

Gambar 3.7. Pengaruh massa adsorben terhadap jumlah ion Fe(II) teradsorpsi 
Grafik pada Gambar 3.7 menunjukkan semakin banyak adsorben yang digunakan maka semakin banyak ion logam yang diadsorpsi, karena ada peningkatan sisi aktif yang memiliki pasangan elektron bebas yang menyebabkan kation logam dapat tertarik. Setiap adsorben memiliki kemampuan untuk mengikat ion-ion logam hingga maksimum, namun ketika melawati batas maksimum maka permukaan adsorben menjadi jenuh untuk mengadorpsi ion logam ${ }^{[22]}$. Secara ekonomis massa adsorben yang kecil yaitu 0,75 gram akan dipilih sebagai massa optimum jumlah ion Fe(II) teradsorpsi.

\subsubsection{Pengaruh konsentrasi adsorbat terhadap jumlahi Fe(II) teradsorpsi.}

Kemampuan penyerapan suatu adsorben dipengaruhi oleh konsentrasi adsorbat. Gambar 3.8 menunjukkan pengaruh konsentrasi adsorbat terhadap jumlah ion Fe(II) teradsorpsi.

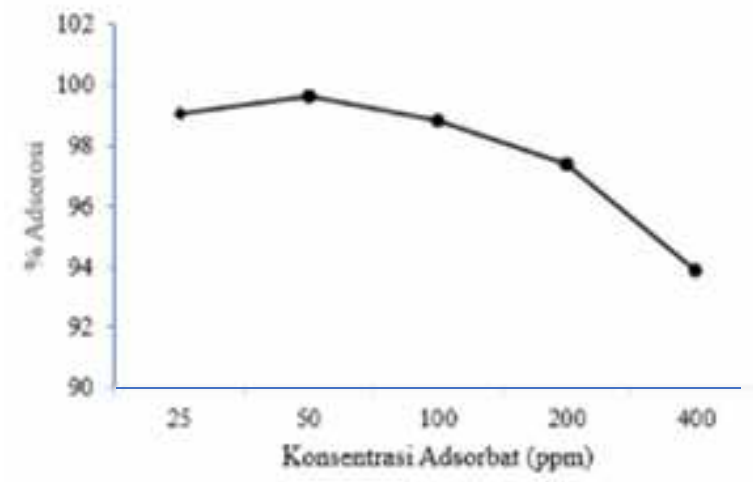

Gambar 3.8 Pengaruh konsentrasi adsorbat terhadap jumlah ion Fe(II) teradsorpsi

Pada gambar 3.8 konsentrasi adsorbat sebesar 50 ppm menunjukkan kapasitas adsorpsi yang paling tinggi. Konsentrasi adsorbat yang semakin besar yaitu pada konsentrasi 100 ppm, 200 ppm, dan 400 ppm justru menunjukkan penurunan adsorpsi, hal ini terjadi karena jumlah adsorbat dalam larutan tidak sebanding dengan jumlah partikel adsorben yang tersedia, dalam hal ini gugus fungsi pada adsorben telah mengalami kejenuhan sehingga kapasitas adsorpsi menurun dan kemungkinan terjadi proses desoprsi atau pelepasan kembali adsorbat dari adsorben.

\subsubsection{Pengaruh Waktu terhadap jumlah ion Fe(II) teradsorpsi}

Waktu digunakan sebagai parameter dalam mengukur kapasitas adsorpsi karena semakin lama adsorbat berada didalam kolom diharapkan semakin banyak ion yang dijerap oleh adsorben.

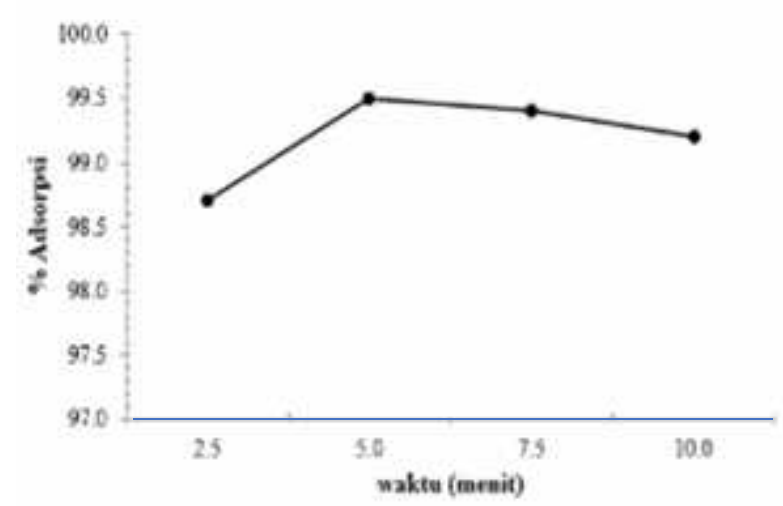

Gambar 3.9 Pengaruh waktu terhadap terhadap jumlah ion Fe(II) teradsorpsi 
Pada gambar 3.9 terlihat waktu yang digunakan pada rentang 2,5 menit, 5,0 menit, 7,5 menit, dan 10 menit tidak menunjukkan perbedaan jumlah ion Fe(II) yang teradsorpsi secara signifikan. Grafik menunjukkan bahwa pada waktu 5 menit terjadi adsorpsi yang paling tinggi. Perbedaan yang tidak signifikan ini diduga terjadi karena rentang waktu yang dipilih terlalu rapat. Penelitian yang dilakukan $^{[23]}$ menghasilkan penyerapan kadar logam Fe menggunakan adsorben batang pisang tertinggi pada waktu kontak 30 menit dengan massa adsorben 2,5 gram, efisiensi yang didapatkan 80,31\%. Adapun adsorpsi ion Fe(II) menggunakan abu layang memperoleh waktu kontak optimum pada menit 60 dengan persen adsorpsi sebesar $70,3 \%^{[24]}$. Semakin lama waktu kontak mengakibatkan interaksi antara JeP-OCa dengan ion Fe(II) semakin besar sehingga semakin banyak ion $\mathrm{Fe}(\mathrm{II})$ yang teradsorpsi oleh JeP-OCa melalui reaksi pertukaran ion.

\subsection{Kinetika Adsorpsi}

Kinetika adsorpsi merupakan satu parameter yang sangat penting dalam memberikan nilai tambah wawasan tentang jalur reaksi, mekanisme reaksi, tingkat penyerapan zat terlarut untuk menentukan model kesetimbangan yang sesuai digunakan pada suatu penelitian, khususnya pada pengolahan air ${ }^{[25]}$. Kinetika adsorpsi yang dipilih pada penelitian ini adalah model pseudo orde satu dan pseudo orde dua. (Gambar 3.12 dan Gambar 3.13). Penentuan model kesetimbangan tergantung pada harga koefisien korelasi $\left(\mathrm{R}^{2}\right)$. Model kesetimbangan yang cocok adalah model kesetimbangan dengan harga $\mathrm{R}^{2}$ yang lebih tinggi atau mendekati 1 .

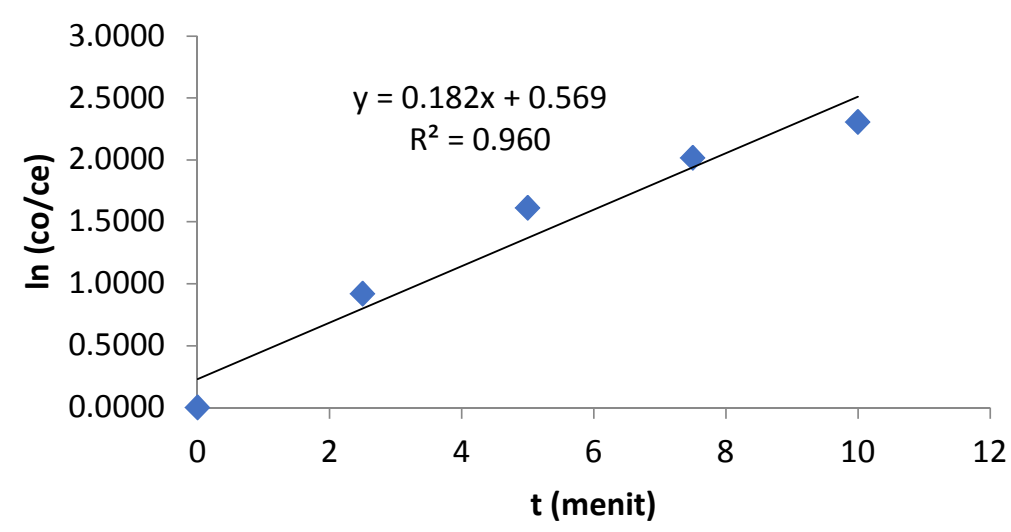

Gambar 3.10 Model kinetika adsorpsi Orde 1

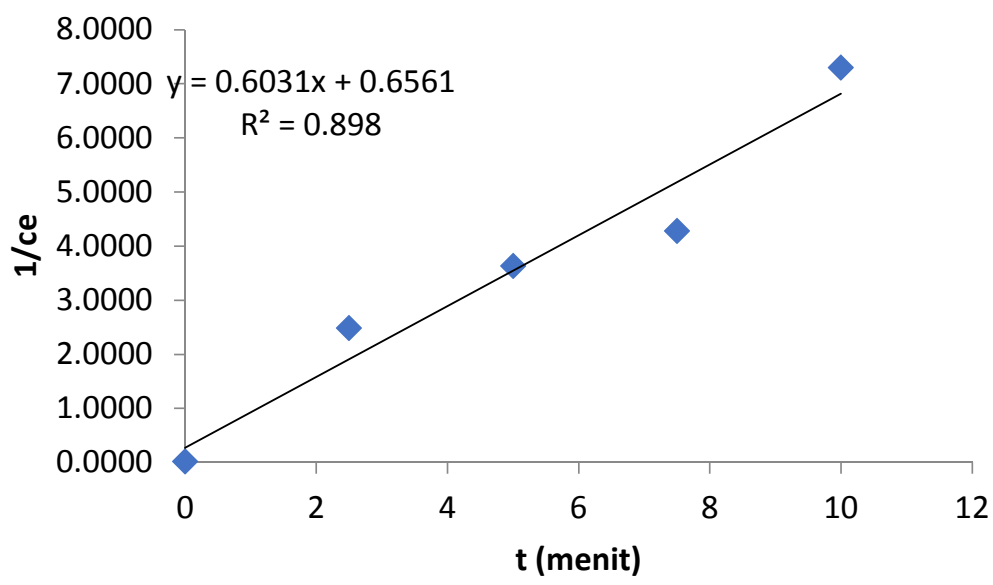

Gambar 3.11 Model kinetika adsorpsi Orde 2 
Berdasarkan Gambar 3.10 dan Gambar 3.11 menunjukkan orde reaksi adsorpsi JeP-OCa terhadap ion Fe(II) mengikuti kinetika adsorpsi orde 1. Hal ini dapat dilihat dari kelinieritasan kurva yang ditunjukkan oleh nilai koefisien korelasi linier. Harga koefisien korelasi linier orde1 lebih besar dibandingkan dengan kurva orde 2 .

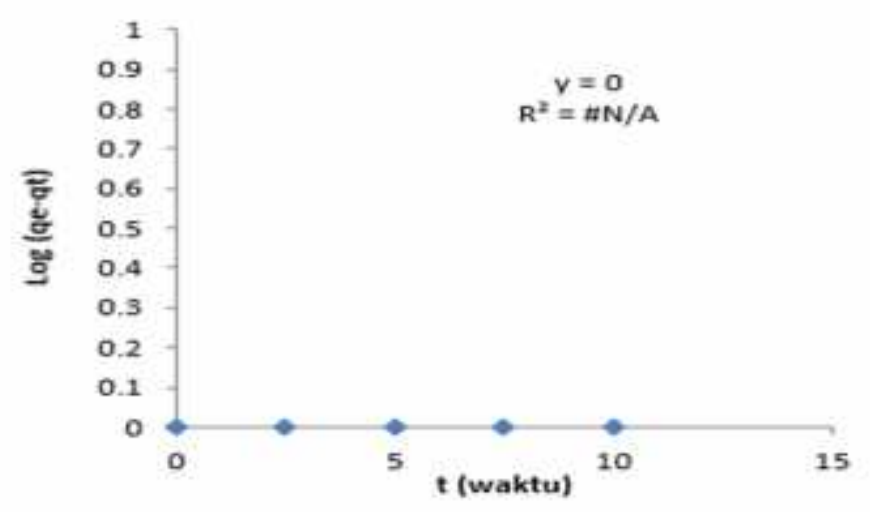

Gambar 3.12 Model kinetika adsorpsi pseudo orde 1

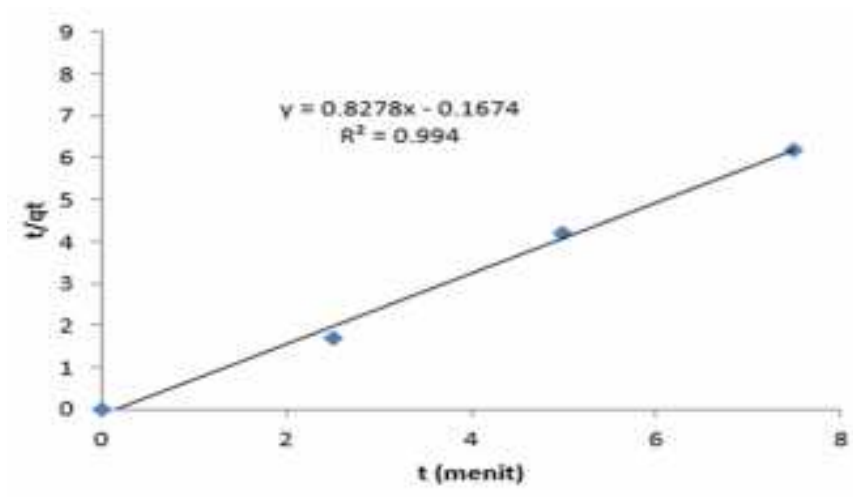

Gambar 3.13 Model kinetika adsorpsi pseudo orde 2

Tabel 3. Persamaan garis, nilai koefisien korelasi $\left(\mathrm{R}^{2}\right)$ dan konstanta laju adsorpsi pada kulit jeruk termodifikasi (JeP-OCa)

\begin{tabular}{|l|l|l|c|}
\hline \multicolumn{1}{|c|}{ Laju reaksi } & \multicolumn{1}{|c|}{ Persamaan garis } & $\begin{array}{c}\text { koefisien } \\
\text { korelasi }\left(\mathrm{R}^{2}\right)\end{array}$ & Koefisien laju (L.mg ${ }^{-1}$. menit) \\
\hline $\begin{array}{l}\text { Orde reaksi satu } \\
\text { Orde reaksi dua }\end{array}$ & $\mathrm{y}=0,182 \mathrm{x}+0,569$ & $\mathrm{R}^{2}=0,960$ & $0,182 \mathrm{~L} / \mathrm{mg}$. menit \\
Pseudo orde satu & - & - & $-6031 \mathrm{x}+0,6561$ \\
$\mathrm{R}^{2}=0,898$ & - \\
Pseudo orde dua & $\mathrm{y}=0,8278 \mathrm{x}-0,1674$ & $\mathrm{R}^{2}=0,994$ & $4,0968 \mathrm{~L} / \mathrm{mg}$. menit \\
\hline
\end{tabular}

Hasil penelitian menunjukkan laju adsorpsi ion Fe(II) pada JeP-OCa mengikuti model kinetika pseudo orde dua yang dapat dilihat dari nilai koefesien korelasinya $\left(\mathrm{R}^{2}\right)$ yang lebih tinggi atau mendekati 1. Dengan nilai konstanta laju sebesar 4,0968 L/ mg.menit. Kesesuaian model laju adsorpsi pseudo orde dua menggambarkan bahwa proses adsorpsi ion Fe(II) pada JeP-OCa dipengaruhi oleh dua spesi reaktan yaitu konsentrasi Fe(II) dan konsentrasi situs aktif pada JePOCa. Fransina dan Tanasale (2007) menyatakan bahwa mekanisme proses adsorpsi pseudo orde dua dijelaskan dengan mengasumsikan bahwa sebagai penentu laju reaksi adalah proses penjerapan 
kimia yang meliputi gaya antar valensi atau pertukaran elektron antara adsorben dan adsorbat, proses pengambilannya yang terdiri dari penjerapan kimia-fisik, pertukaran ion, pengendapan atau pembentukan kompleks. Sehingga dapat disimpulkan bahwa pada proses adsorpsi terjadi interaksi secara kimia sesuai tipe isoterm adsorpsi model Langmuir dan sejalan pula dengan hasil isoterm adsorpsi model Freundlich yang menyatakan bahwa adsorpsi terjadi pada permukaan adsorben yang heterogen.

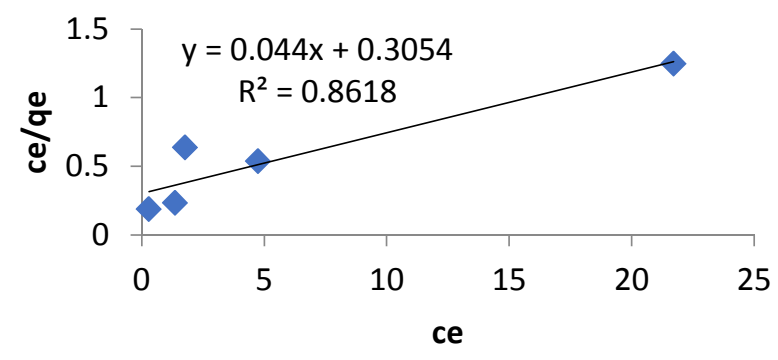

Gambar 3.14 Persamaan Isoterm Langmuir

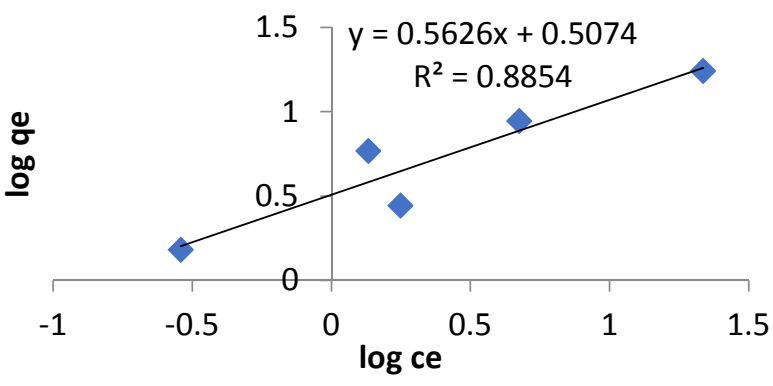

Gambar 3.15 Persamaan Isoterm Freundlich

Tabel 4. Konstanta isoterm Langmuir dan Freundlich untuk adsorpsi Fe(II) oleh JeP-Oca

\begin{tabular}{|c|c|c|c|c|c|c|}
\hline Isoterm & Nilai $\mathrm{Y}$ & $\mathrm{R}^{2}$ & $\begin{array}{c}\mathrm{q}_{\mathrm{m}} \\
(\mathrm{mg} / \mathrm{g})\end{array}$ & $\begin{array}{c}\mathrm{K}_{\mathrm{L}} \\
(\mathrm{L} / \mathrm{mg})\end{array}$ & $\mathrm{n}$ & $\mathrm{K}_{\mathrm{f}}$ \\
\hline Langmuir & $0,044 \mathrm{x}+0,3054$ & 0,8618 & 22,7272 & 0,1442 & - & - \\
Freundlich & $0,5626 \mathrm{x}+0,5074$ & 0,8854 & - & - & 1,9011 & 3,2136 \\
\hline
\end{tabular}

Isoterm adsorpsi menunjukkan adanya hubungan antara banyaknya zat yang teradsorpsi dengan konsentrasi zat terlarut. Tipe isoterm adsorpsi untuk mempelajari mekanisme adsorpsi fase cair-padat pada umumnya menganut tipe isoterm Langmuir dan Freundlich ${ }^{[27]}$. Pada penelitian ini, adsorpsi Fe(II) oleh JeP-OCa mengikuti dua persamaan, yaitu persamaan Langmuir dan Freundlich. Pada penelitian ini kurva isoterm kedua model ini diperoleh persamaan korelasi yang digunakan untuk menentukan kapasitas adsorpsi maksimum.

Tipe isoterm Langmuir merupakan proses adsorpsi yang berlangsung secara kimisorpsi satu lapisan, yaitu adsorpsi yang terjadi melalui ikatan kimia yang sangat kuat antara sisi aktif permukaan dengan molekul adsorbat dan dipengaruhi oleh densitas elektron. Adapun isoterm Freundlich menggambarkan hubungan antara jumlah komponen yang teradsorpsi per unit adsorben dan konsentrasi komponen tersebut pada kesetimbangan ${ }^{[28]}$.

Gambar 3.14 dan Gambar 3.15 diatas menunjukkan bahwa adsorpsi Fe(II) oleh kulit jeruk termodifikasi $\mathrm{Ca}(\mathrm{OH})_{2}$ cenderung mengikuti isoterm Freundlich yang terlihat dari nilai koefisien 
korelasi $\left(R^{2}\right)$ sebesar 0,8854 lebih tinggi dibandingkan nilai koefisien korelasi $\left(R^{2}\right)$ pada persamaan Langmuir sebesar 0,8618. Hal ini menunjukkan bahwa adsorpsi berlangsung secara fisisorpsi multilayer. Ion $\mathrm{Fe}(\mathrm{II})$ yang teradsorpsi relatif bertambah dengan cepat seiring bertambahnya konsentrasi kemudian melambat jika permukaan adsorben tertutup oleh adsorbat. Gaya Van Der Waals yang mengikat adsorbat dengan adsorben bersifat lemah, kondisi yang memungkinkan adsorbat leluasa bergerak sehingga proses adsorpsi berlangsung di banyak lapisan. Dengan kata lain terbentuk lapisan adsorpsi kedua dan seterusnya di atas adsorbat yang telah terikat di permukaan. Berbeda dengan model isoterm Langmuir, permukaannya homogen dan hanya dapat mengadsorpsi satu molekul adsorbat untuk setiap molekul adsorbennya, masing-masing situs aktif hanya dapat mengadsorpsi satu molekul adsorbat saja sehingga adsorpsi hanya akan terbatas pada pembentukan lapisan tunggal (monolayer) ${ }^{[29]}$.

Seperti penelitian yang dilakukan oleh ${ }^{[30]}$ tentang penggunaan biomassa kulit buah naga untuk mengadsorpsi $\mathrm{Cu}$ (II) diperoleh koefidien korelasi $\left(\mathrm{R}^{2}\right)$ Langmuir $=0,995$ dan koefidien korelasi $\left(R^{2}\right)$ Freundlich $=0,968$. Dari persamaan kesetimbangan yang diperoleh dapat dilihat persamaan mana yang lebih mewakili reaksi yang terjadi, apakah reaksi terjadi secara fisisorpsi atau kimisorpsi. Meski adsorpsi menggunakan kulit buah naga menunjukkan koefisien korelasi model isoterm Langmuir yang lebih baik namun koefisien korelasi model isoterm Freundlich juga sudah memenuhi dalam mengadsorpsi ion $\mathrm{Cu}(\mathrm{II})$, dan pada JeP-OCa berdasarkan pada koefisien korelasi $\left(\mathrm{R}^{2}\right)$ maka model isoterm adsorpsi Langmuir terpenuhi namun isoterm adsorpsi Freundlich lebih baik digunakan untuk menyerap ion Fe(II).

\subsection{Aplikasi Adsorben pada Air Tanah}

Pada penelitian ini air yang digunakan adalah air tanah dangkal (air sumur). Air sumur atau air tanah umumnya memiliki kation dan anion yang terlarut, salah satunya adalah Fe. Menurut ${ }^{[31]}$ air sumur atau air tanah memiliki kandungan Fe yang tinggi. Pada air tanah dengan oksigen yang rendah kadar besi bisa mencapai 10-100 mg/L. Tingginya kandungan Fe pada air tanah atau air sumur dikarenakan air permukaan mengalami kontak langsung dengan mineral-mineral yang terdapat dalam tanah, dengan demikian kualitas air akan mengalami perubahan. Adanya perubahan kualitas air dengan kandungan Fe yang tinggi dapat dilihat dari keadaan fisik air yakni warna dan bau. Keberadaan Fe dalam air dapat berbentuk Fe(II) atau Fe(III). Air tanah yang digunakan pada penelitian ini diambil di Jl. Darma Putra Pontianak Utara. Sebelum digunakan air tanah terlebih dahulu dianalisis dengan AAS untuk mengetahui kandungan $\mathrm{Fe}$ dalam air tanah. Hasil analisis diketahui bahwa Fe yang terkandung dalam air tanah sebesar 1,2542 mg/L. Proses adsorpsi air tanah dilakukan dengan menggunakan kondisi optimum yang diperoleh pada penelitian ini. Dari hasil analisis diperoleh efisiensi adsorpsi sebesar 82,99\%.

Efisiensi adsopsi $\mathrm{Fe}$ (II) pada air tanah dengan menggunakan JeP-OCa menurun dibandingkan dengan Fe(II) sintetik. Menurut Polintang (2011) dalam ${ }^{[32]}$ selain Fe(II) pada air tanah juga terkandung ion-ion logam lain seperti $\mathrm{Mn}(\mathrm{II}), \mathrm{Zn}(\mathrm{II}), \mathrm{Cu}(\mathrm{II}), \mathrm{Ca}(\mathrm{II}), \mathrm{Mg}(\mathrm{II})$ dan Na(II), ion-ion logam tersebut juga dapat berinteraksi dengan adsorben. Keberadaan ion-ion logam selain Fe(II) diperkirakan sebagai salah satu penyebab menurunnya nilai efisiensi adsorpsi Fe (II) pada air tanah.

\section{Simpulan}

Berdasarkan penelitian yang telah dilakukan maka dapat disimpulkan bahwa :

1. Kulit jeruk Citrus nobilis Lour. var microcarpa yang termodifikasi $\mathrm{Ca}(\mathrm{OH})_{2}(\mathrm{JeP}-\mathrm{OCa})$ mengandung gugus fungsi $-\mathrm{OH}$ dan $-\mathrm{COOH}$ serta memiliki permukaan dengan karakteristik serat 
2. Adsorpsi ion Fe(II) pada JeP-OCa secara maksimal diperoleh pada $\mathrm{pH}$ 4-6. Adsorpsi ini mengikuti model isoterm Freundlich dengan nilai kapasitas maksimum adsorpsi sebesar 22,7272 mg/g. Aplikasi adsorpsi menggunakan air tanah menghasilkan efisiensi penyerapan sebesar 82,99\%.

3. Adsorpsi ion $\mathrm{Fe}(\mathrm{II})$ pada JeP-OCa memenuhi kinetika reaksi pseudo orde 2 dengan nilai konstanta laju sebesar 4,097 L/mg.menit

\section{Daftar Pustaka}

[[1] Ignasius D.A. Sutapa,LIPI, Kajian Jar Test Koagulasi Flokulasi Sebagai Dasar Perancangan Instalasipengolahan Air Gambut (Ipag) Menjadi Air Bersih

[2] Kepmenkes, 1990, Peraturan Menteri Kesehatan Republik Indonesia No. 416/MENKES/PER/IX/1990 tentang Syarat-syarat dan Pengawasan Kualitas Air, Menteri Kesehatan Republik Indonesia, Jakarta

[3] Darmono., 2001, Lingkungan Hidup dan Pencemaran, Jakarta: Universitas Indonesia Press

[4] Agmalini, S. 2013. Peningkatan Kualitas Air Rawa Menggunakan Membran Keramik Berbahan Tanah Liat Alam dan Abu terbang batubara. Jurnal Teknik Kimia No. 2, Vol. 19.

[5] Suherman, D. dan Nyoman Sumawijaya 2013, Menghilangkan Warna dan Zat Organik Air Gambut dengan Metode Koagulasi-Flokulasi Suasana Basa. Vol. 23, No.2, 127-139.

[6] Puspita, U. dkk., ,2011, Kemampuan Tumbuhan Air sebagai Agen Fitoremediator logam Berat Kromium ( $\mathrm{Cr}$ ) yang Terdapat pada Limbah Cair Industri Batik. Jurnal Volume 39 no. 1.

[7] Xing G-x, Zhang S-f, Ju B-z, Yan J-z. 2006, Study on adsorption behavior of cross linked cationic star chmaleate for chromium(VI). Carbohydr.Polym. 66.246-25.

[8] Badan Pusat Statistik. 2010. Data produksi jeruk pontianak 2005-2010. BPS Kabupaten Sambas. Kalimantan Barat.

[9] Wilkins MR, Widmer WW, Grohmann K. 2007, Simultane ous saccharification and fermentation of citrus peel waste by Saccharomyces cerevisiae to produce ethanol. Process Biochem. 42. 1614-1619.

[10] Mamma D, Kourtoglou E, Christakopoulos P. 2008. Fungal multienzyme production on industrial by-products of the citrus-processing industry. Bioresour. Technol. 99. 2373-2383.

[11] Shan W, Fang D, Zhao Z, Shuang Y, Ning L, Xing Z, Xiong Y. (2012). Aplication of orange peel for adsorption separation of molybdenum (VI) from recontaining industrial effluent, Biomass and Bioenergy. 37, 289-297.

[12] Buchari, Toha,2010. Optimasi Proses Saponifikasi Kulit Jeruk Dengan Ca(OH)2 Dan Di Aktivasi Zirkonium Untuk Adsorben Ion Arsenik Dan Fosfor. Teknik Kimia,Universitas Brawijaya.

[13] Vinisyanty I. 2013, Kajian Adsorbsi Pb(II) dengan Adsorben Limbah Jeruk Tersaponifikasi $\mathrm{Ca}(\mathrm{OH})_{2}$ dan $\mathrm{NaOH}$. (tesis), Universitas Gadjah Mada, Yogyakarta.

[14] Sulihono, A. 2012, Pengaruh Waktu, Temperatur, dan Jenis pelarut terhadap Ekstraksi Pektin dari Kulit Jeruk Bali (Citrus maxcima). Jurusan Teknik Kimia Fakultas Teknik Universitas Sriwijaya, Vol 18 no 4.

[15] Lasheen .R dkk., 2012, Adsorption/Desorption Of Cd(II), Cu(II) And Pb(II) Using Chemically Modifiedorange Peel: Equilibrium And Kinetic Studies Solid State Sciences 14 (2012) 202e210.

[16] Feng dkk.,2010, Enhanced Cu(II) Adsorption By Orange Peel Modified With Sodium Hydroxide, Science Press s146-s152

[17] Nur Fitria Nella Wati, 2014. Peningkatan Kualitas Minyak Nilam Melalui Proses Adsorpsi Menggunakan Adsorben $\gamma$ Alumina Dengan Sistem Flow. Indonesian Journal of Chemical Research Using Bios, Volume 1. 
[18] Igwe, JC., Abia, AA, 2006. Abioseparation Process for Removing Heavy Metals from Waste Water Using Biosorbents, African Journal of Biotechnology, 5.

[19] Guo, dkk., 2010, Isotherm, Kinetik and Thermodynamic Studies of Adsorption of $\mathrm{Cu}^{2+}$ from Aqueous Solution by $\mathrm{Mg}^{2+} / \mathrm{K}^{+}$Type orange Peel Adsorbent,National Natural Science Foundation.

[20] Putra A. dan Fitri W., 2016, KARAKTERISASI Pertukaran Ion Timbal (II) dengan Kalsium pada Proses Biosorpsi Alga Hijau Cladophora fracta, Jurnal Iptek Terapan Vol. 8 Hal 103-111.

[21] Griffin. B,dkk., 1991 Environmental Scanning Electron Microscopic Study Of Macrophages Associated With The Tunica Vasculosa Lentis In The Developing Rat Eye.Britis Journal of Ophthalmology.

[22] Suryaningtyas dkk., 2014, Kemampuan Pektin Kulit Jeruk Manis (Citrus sinensis) sebagai Biosorben Logam Berat krom (VI), Fakultas Teknobiologi, Universitas Atma Jaya Yogyakarta

[23] Suziyana 2017, Pengaruh Massa Adsorben Batang Pisang dan Waktu Kontak Adsorpsi Terhadap Efisiensi Penyisihan Fe dan Kapasitas Adsorpsi Pada Pengolahan Air Gambut. Jom FTEKNIK Volume 4 No.1

[24] Irawan C., dkk., 2015, Pengaruh Massa Adsorben, Lama Kontak Dan Aktivasi Adsorben Menggunakan $\mathrm{HCl}$ Terhadap Efektivitas Penurunan Logam Berat (Fe)Dengan Menggunakan Abu Layang Sebagai Adsorben. Jurnal Teknologi Terpadu Vol. 3 No. 2.

[25] Ho, Y.S. dan G. McKay.1997, Pseudo-second order model for sorption processes Process Biochemistry 34 (1999) 451-46.

[26] Fransina E.G dan Tanasale Matheis F.J.D.P, 2007. Studi Kinetika Adsoorpsi Biru Metilen pada Kitin dan Kitosan. J. Sains MIPA. Vol. 13 No. 3 Hap.171-176.

[27] Atkins, P.W. 1990. Kimia Fisika Jilid 2 Edisi Keempat. Penerbit Erlangga. Jakarta.

[28] Rosen, M. J. (1989). Surfactants and Interfacial Phenomena. New York, John Willey\&Sons.

[29] Hartati.I, dkk, 2011, Potensi Xanthate Pulpa Kopi Sebagai Adsorben Pada Pemisahan Ion Timbal Dari Limbah Industri Batik. Momentum, Vol. 7, No. 2, Oktober 2011 : 25- 30

[30] Ali, S., 2015, Biosorpsi Ion Logam Cu (II) oleh Kulit Buah Naga (Hylocereus polyrhizus), (Skripsi), Universitas Hasanuddin, Makassar.

[31] Effendi, H., 2007, Teknik Kualitas Air: bagi Pengolahan Sumber Daya dan Lingkungan Perairan, Yogyakarta: Kanisius.

[32] Sari, D.R., Destiarti, L. \& Wahyuni, N., 2014), Sintesis Pasir Kuarsa Terlapis mangan Dioksida dan Optimasi pH dalam Menurunkan Kadar Besi pada Tanah, Jurnal Kimia Khatulistiwa, 3(4), pp.26-31. 